\title{
The effect of oversewing the staple line in laparoscopic sleeve gastrectomy: randomized control trial
}

\author{
Andrzej Kwiatkowski, Michał R. Janik, Krzysztof Paśnik, Edward Stanowski \\ Department of General, Oncologic, Metabolic and Thoracic Surgery, Military Institute of Medicine, Warsaw, Poland
}

Videosurgery Miniinv 2016; 11 (3): 149-155

DOI: $10.5114 /$ wiitm.2016.62801

\begin{abstract}
Introduction: Laparoscopic sleeve gastrectomy (LSG) is one of the most popular bariatric procedures. The procedure is associated with serious staple-line complications such as bleeding, leaks, and stenosis.

Aim: To determine whether oversewing the staple line, compared with clipping, in LSG reduces the incidence of postoperative bleeding.

Material and methods: We conducted a parallel-group, prospective, randomized controlled trial (RCT) of 100 patients who underwent LSG for obesity at a single institution between May 2014 and August 2015. Patients were assigned to one of two groups for reinforcement of the staple line: the oversewing group (staple line oversewn) or the clipping group (staple line clipped). The primary outcome was reoperation for hemodynamic instability caused by staple-line bleeding within $72 \mathrm{~h}$ postoperatively. The secondary outcomes were operative duration, length of hospital stay, postoperative leaks, and postoperative stenosis.

Results: Mean operative duration was longer in the oversewing group (78.2 $\pm 20.5 \mathrm{~min})$ than in the clipping group (64.1 $\pm 16.5 \mathrm{~min}, p<0.001)$. Mean length of hospital stay was comparable in both groups. Postoperatively, there was no significant between-group difference in bleeding (oversewing, $n=0$ vs. clipping, $n=2(4.6 \%) ; p=0.21$ ) or in stenosis and leakage (both outcomes: oversewing, $n=0$, vs. clipping, $n=1$ (2.3\%); $p=0.46$ ).

Conclusions: Oversewing the staple line prolongs operative duration. No conclusions can be drawn regarding the effects of oversewing on staple-line bleeding, postoperative leakage and stenosis, or length of hospital stay.
\end{abstract}

Key words: sleeve gastrectomy, staple line, bleeding, leak, reinforcement, oversewing.

\section{Introduction}

Laparoscopic sleeve gastrectomy (LSG) is one of the most popular bariatric procedures $[1,2]$. It is relatively simple and effective in terms of excess weight loss [3], but it is associated with serious staple-line complications such as bleeding, leaks, and stenosis, which persist despite advances in the technology of surgical stapling devices [4-6]. Therefore, surgeons are interested in any maneuvers that can minimize the risk of these events. The three main options for staple-line reinforcement are: 1) oversewing, and buttressing with 2) synthetic poly- mers or 3) biologic tissue. In their meta-analysis, Shikora et al. found that, compared with do nothing, all three options are effective [7]. However, the term do nothing is misleading because there are surgical maneuvers that can contribute to reducing the incidence of bleeding or leakage without staple-line reinforcement. First, a stapler of adequate size for the thickness of the gastric wall should be chosen. Second, proper stapling technique should be applied. Finally, bleeding can be avoided by clipping the staple line [8]. Many studies attempting to compare maneuvers did not address variations in

\section{Address for correspondence}

Michał R. Janik, Department of General, Oncologic, Metabolic and Thoracic Surgery, Military Institute of Medicine, 128 Szaserów St,

04-141 Warsaw, Poland, phone: +48 602780 960, e-mail: janiken@gmail.com 
stapler type, stapling technique, and clip use among surgeons; therefore, these studies could not compare suturing patterns.

\section{Aim}

The objective of this study was to determine whether the incidence of staple-line bleeding in the postoperative period after LSG was lower with staple-line oversewing using a continuous extraserosal invaginating suture than with clipping.

\section{Material and methods}

\section{Study design}

One hundred patients who underwent LSG at a single bariatric institution between May 2014 and August 2015 were included in a non-blinded, prospective, randomized controlled trial comparing the effect of oversewing of the staple line versus clipping.

\section{Study population}

We assessed the eligibility of all bariatric patients admitted to our center who met the following criteria for bariatric surgery: body mass index (BMI) $>40 \mathrm{~kg} / \mathrm{m}^{2}$, or $\mathrm{BMI}>35 \mathrm{~kg} / \mathrm{m}^{2}$ with comorbidities, for $>5$ years and failed conservative treatment for $>2$ years. We excluded from the study those who had previously undergone a bariatric procedure, including adjustable silicone gastric banding or vertical banded gastroplasty, and patients older than 65 years of age or with $\mathrm{BMI}>60 \mathrm{~kg} / \mathrm{m}^{2}$.

\section{Description of procedure and postoperative management}

The patient was placed supine in a reverse Trendelenburg position with the shoulders abducted $90^{\circ}$. Five trocars were used. The dissection of the greater curvature was started 3 to $4 \mathrm{~cm}$ from the pylorus. The gastrocolic ligament was cut to the angle of His. The left diaphragmatic crus was exposed. A 36-French probe was passed orally into the pylorus and placed against the lesser curvature. A laparoscopic stapler was introduced and fired consecutively along the length of the probe until the angle of His was reached. We used two different staplers: (1) the Echelon Flex Powered Endopath stapler (Ethicon Endosurgery, Inc., Somerville, NJ, USA) with gold cartridges, or (2) the Endo GIA (Covidien/
Medtronic, Inc., Mansfield, MA, USA) with purple cartridges for the first 2 firings and blue cartridges for the remainder. The surgeon waited about $20 \mathrm{~s}$ after closing the stapler before each firing process was initiated. The resected stomach specimen was then removed by enlarging one of the $12-\mathrm{mm}$ ports. After testing for leaks with methylene blue dye $(100 \mathrm{ml})$, a drain was placed alongside the staple line. All patients underwent an additional test with methylene blue solution on postoperative day 1 . If no leakage was detected, an oral diet was resumed. The patients were discharged on postoperative day 2 . All procedures were performed by a single high-volume (> 100 cases per year) bariatric surgeon.

\section{Study intervention}

Patients were randomly assigned to the oversewing group or the clipping group. Both groups underwent the LSG procedure described above. In the oversewing group, the entire staple line was reinforced with a continuous extraserosal invaginating suture using 3-0 Biosyn Monofilament Absorbable Suture (Medtronic Inc., Minneapolis, MN, USA). In the clipping group, Covidien Endo Clip II ML $10 \mathrm{~mm}$ (Covidien/Medtronic, Inc., Mansfield, MA, USA) was applied to areas of bleeding or to any vessels cut by the stapler. No additional reinforcement was used.

\section{Randomization, allocation concealment, and sample size}

A research coordinator randomly assigned the patients to groups using block randomization. The randomization list containing the unique number linked to type of intervention was generated using a randomization-plan generator (available at www. randomization.com). The numbers were stored in a box. Before each procedure the research coordinator picked one number from the box and allocated the patient to a type of intervention, and the number was then removed from the box. Because this was a pilot study, a sample size was not calculated.

\section{Study outcomes}

The primary outcome was defined as reoperation for staple-line bleeding within $72 \mathrm{~h}$ postoperatively. Secondary outcomes were operative duration, length of hospital stay, and postoperative leakage and stenosis occurring up to 30 days postoperatively. 


\section{Literature review}

A review of the literature was performed. Articles were identified by searching the PubMed database for staple-line reinforcement AND sleeve gastrectomy. We focused on English-language articles that reported the results of randomized controlled trials.

\section{Statistical analysis}

Analysis was performed using SAS software, University Edition (SAS Institute Inc., Cary, NC, USA). Continuous variables were compared using the Mann-Whitney $U$ test and Student's $t$-test as appropriate. Categorical variables were compared using Fisher's exact test. Differences with a $p$-value $<0.05$ were considered statistically significant.

\section{Results}

\section{Study population}

Of the 106 patients screened for eligibility, 100 (mean age: $38.2 \pm 10.3$ years; mean BMI: $47.6 \pm 8.7$ $\mathrm{kg} / \mathrm{m}^{2}$ ) met the eligibility criteria and were randomized to the oversewing and clipping groups. Seven patients allocated to the clipping group did not receive the allocated intervention because of difficulties maintaining hemostasis during surgery; the surgeon felt that those patients required oversewing of at least part of the staple line to stop intraoperative bleeding (Figure 1). Baseline demographic and clinical characteristics were similar in both groups (Table I). There was no between-group difference in the type of stapler used (Table II).

\section{Enrollment}
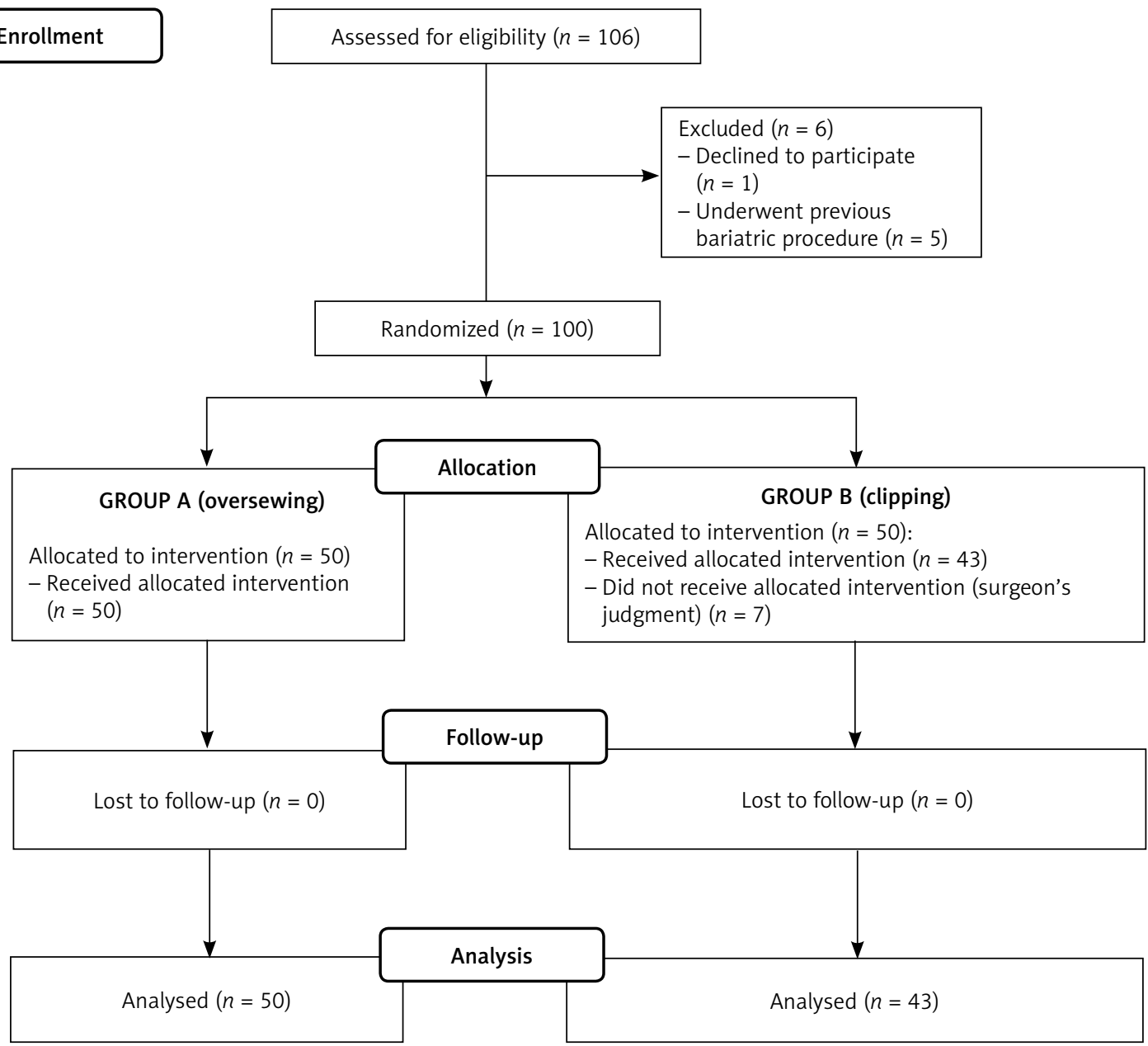

Figure 1. Flow diagram 
Table I. Baseline characteristics

\begin{tabular}{|c|c|c|c|}
\hline \multirow[t]{2}{*}{ Patient characteristic } & \multicolumn{2}{|c|}{ Intervention groups } & \multirow[t]{2}{*}{$P$-value } \\
\hline & $\begin{array}{l}\text { Oversewing } \\
\qquad(n=50)\end{array}$ & $\begin{array}{l}\text { Clipping } \\
(n=43)\end{array}$ & \\
\hline Age [years] & $36.8 \pm 10.3$ & $39.5 \pm 10.5$ & $0.26^{a}$ \\
\hline BMI [kg/m²] & $49.0 \pm 8.5$ & $45.7 \pm 9.0$ & $0.14^{b}$ \\
\hline Sex ratio, female/male & $27 / 23$ & $19 / 24$ & $0.41^{c}$ \\
\hline $\begin{array}{l}\text { Previous abdominal } \\
\text { non-bariatric surgery }\end{array}$ & $5(10 \%)$ & $7(16 \%)$ & $0.53^{c}$ \\
\hline \multicolumn{4}{|l|}{ Comorbidities: } \\
\hline Hypertension & $26(52 \%)$ & 17 (39\%) & $0.29^{c}$ \\
\hline Diabetes & $10(20 \%)$ & $9(21 \%)$ & $1.0^{c}$ \\
\hline Dyslipidemia & $5(10 \%)$ & $4(9 \%)$ & $1.0^{c}$ \\
\hline
\end{tabular}

Data expressed as mean \pm standard deviation, $n$, or $n(\%)$. ' Student's $t$ test. ${ }^{b}$ Mann-Whitney $U$ test. 'Fisher's exact test. BMI - body mass index.

Table III. Prevalence of primary outcome in both groups

\begin{tabular}{|c|c|c|c|c|}
\hline \multirow{2}{*}{$\begin{array}{l}\text { Primary } \\
\text { outcome }\end{array}$} & \multicolumn{2}{|c|}{ Intervention groups } & \multirow[t]{2}{*}{$P$-value } & \multirow{2}{*}{$\begin{array}{l}\text { Risk ratio } \\
(95 \% \mathrm{Cl})\end{array}$} \\
\hline & $\begin{array}{l}\text { Oversewing } \\
\quad(n=50)\end{array}$ & $\begin{array}{l}\text { Clipping } \\
(n=43)\end{array}$ & & \\
\hline $\begin{array}{l}\text { Reoperation due } \\
\text { to staple-line } \\
\text { bleeding }\end{array}$ & $0(0 \%)$ & $2(4.6 \%)$ & $0.21^{a}$ & $\begin{array}{c}\text { Not } \\
\text { estimable }\end{array}$ \\
\hline
\end{tabular}

\section{Incidence of primary outcome: bleeding}

Among patients in the clipping group, 2 (4.6\%) met our primary outcome. Those patients underwent laparoscopic evacuation of a large hematoma and hemostasis of staple-line bleeding. None of the patients in the oversewing group met the primary outcome criterion. The risk ratio was not estimable (Table III). The difference in incidence of the primary outcome between groups was not statistically significant.

\section{Incidence of secondary outcome: leakage and stenosis}

In 1 (2.3\%) patient from the clipping group, an early leak was diagnosed on postoperative day 10 . Bleeding had been diagnosed in this patient on postoperative day 3; repeat laparoscopy had been performed and hemostasis controlled, and the patient was discharged in good condition on postoperative day 7. The patient was readmitted to our department on postoperative day 10 complaining of abdominal pain and fever. Computed tomography revealed a type II leak [9]. The
Table II. Stapler data

\begin{tabular}{|cccc|}
\hline \multirow{2}{*}{$\begin{array}{c}\text { Stapler } \\
\text { manufacturer }\end{array}$} & \multicolumn{2}{c}{ Intervention groups } & \multirow{2}{*}{$P$-value } \\
\cline { 2 - 3 } & Oversewing & Clipping & \\
\hline $\begin{array}{c}\text { Ethicon/ } \\
\text { Covidien }\end{array}$ & $27 / 23$ & $24 / 19$ & $1.0^{\text {a }}$ \\
\hline
\end{tabular}

aFisher's exact test.

Table IV. Prevalence of secondary outcomes in both groups

\begin{tabular}{|c|c|c|c|}
\hline \multirow{2}{*}{$\begin{array}{l}\text { Secondary } \\
\text { outcomes }\end{array}$} & \multicolumn{2}{|c|}{ Intervention groups } & \multirow[t]{2}{*}{$P$-value } \\
\hline & $\begin{array}{l}\text { Oversewing } \\
\quad(n=50)\end{array}$ & $\begin{array}{l}\text { Clipping } \\
(n=43)\end{array}$ & \\
\hline $\begin{array}{l}\text { Operative duration } \\
{[\mathrm{min}]}\end{array}$ & $78.2 \pm 20.5$ & $\begin{array}{r}64.1 \\
\pm 16.5\end{array}$ & $<0.01^{a *}$ \\
\hline $\begin{array}{l}\text { Length of hospital } \\
\text { stay [days] }\end{array}$ & $3.2 \pm 0.4$ & $3.6 \pm 1.3$ & $0.32^{a}$ \\
\hline $\begin{array}{l}\text { Postoperative } \\
\text { leakage }\end{array}$ & $0(0.0 \%)$ & $1(2.3 \%)$ & $0.46^{b}$ \\
\hline $\begin{array}{l}\text { Postoperative } \\
\text { stenosis }\end{array}$ & $0(0 \%)$ & $1(2.3 \%)$ & $0.46^{b}$ \\
\hline
\end{tabular}

$U$ test. ${ }^{b}$ Fisher's exact test. *Significant value.

patient underwent surgical drainage and received nutritional support. Two months after surgical treatment, upper endoscopy was performed, which revealed a fistula in the gastric antrum. To control the leak, a self-expandable covered stent was placed at the level of the gastroesophageal junction for 4 weeks. After removal of the stent, no leak was present. No patient in the oversewing group developed a leak during the first 30 days following the procedure. The risk ratio for postoperative leaks was not estimable, and the difference in incidence was not statistically significant. In the clipping group, 1 case of stenosis (2.3\%) was diagnosed within the first 30 days of follow-up. The patient was readmitted to our department because of persistent emesis. Gastroscopy revealed stricture of the sleeve, and the patient was treated with endoscopic dilation. In the oversewing group, no stenosis was observed during the postoperative period. The risk ratio was not estimable, and the difference in incidence of postoperative stenosis was not statistically significant (Table IV).

\section{Secondary outcome: operative duration and length of hospital stay}

The mean operative duration was significantly longer in the oversewing group $(78.2 \pm 20.4 \mathrm{~min}$, range: 
40.0-150.0 min; median 75 min) than in the clipping group (64.1 $\pm 16.5 \mathrm{~min}$, range: $40.0-115.0 \mathrm{~min}$; median: $60.0 \mathrm{~min})(p<0.01)$. Mean length of hospital stay was similar between groups (Table IV).

\section{Discussion}

The present study showed that, in obese patients who underwent LSG, oversewing the staple line compared with clipping did not affect the rate of reoperation due to staple-line bleeding. However, it is clinically significant that the primary outcome was present in 2 patients in the clipping group but none in the oversewing group.

The differences in postoperative leakage and postoperative stenosis between groups were not significant. The length of hospital stay was also comparable between groups. However, our analysis revealed that total operative duration was significantly longer in the oversewing group. Another clinically significant result is that $14 \%$ of patients who were allocated to the clipping group did not receive the intervention. In those patients, the use of clips alone was insufficient to control intraoperative bleeding, and the surgeon decided to oversew at least part of the staple line.

A limitation of our study is low statistical power because of its small sample size. Considering the low rate of reoperation due to staple-line bleeding in the present study, our results were inconclusive. In future studies of the efficacy of oversewing, the

Table V. Literature review: randomized controlled trials

\begin{tabular}{|c|c|c|c|c|c|c|}
\hline \multirow{2}{*}{$\begin{array}{l}\text { Author, } \\
\text { year }\end{array}$} & \multirow[t]{2}{*}{ Group (n) } & \multirow[t]{2}{*}{ Intervention } & \multicolumn{3}{|c|}{ Outcomes } & \multirow{2}{*}{$\begin{array}{l}\text { Conclusion (statistically } \\
\text { significant difference } \\
\text { between/among groups }\end{array}$} \\
\hline & & & $\begin{array}{c}\text { Staple-line } \\
\text { bleeding }\end{array}$ & Stenosis & $\begin{array}{l}\text { Gastric } \\
\text { leak }\end{array}$ & \\
\hline \multirow{4}{*}{$\begin{array}{l}\text { Carandina } \\
\text { et al. } 2016 \\
{[16]}\end{array}$} & A (150) & No SLR & 1 & 2 & 3 & \multirow[t]{4}{*}{ No } \\
\hline & B (150) & SLR with fibrin glue & 2 & 2 & 4 & \\
\hline & C (150) & $\begin{array}{l}\text { Imbricating absorbable } \\
\text { running suture }\end{array}$ & 1 & 1 & 3 & \\
\hline & D (150) & Barbed running suture & 1 & 2 & 4 & \\
\hline \multirow{2}{*}{$\begin{array}{l}\text { Aggarwal } \\
\text { et al. } 2013 \\
{[13]}\end{array}$} & $A(30)$ & Running suture & 0 & 0 & 0 & \multirow[t]{2}{*}{ No } \\
\hline & B (30) & No SLR & 1 & 0 & 2 & \\
\hline \multirow{3}{*}{$\begin{array}{l}\text { Gentileschi } \\
\text { et al. } 2012 \\
{[14]}\end{array}$} & A (35) & Running suture & 1 & 0 & 1 & \multirow[t]{3}{*}{ No } \\
\hline & B (34) & GORE SEAMGUARD ${ }^{a}$ & 1 & 0 & 0 & \\
\hline & C (33) & FLOSEAL $^{b}$ & 0 & 0 & 1 & \\
\hline \multirow{2}{*}{$\begin{array}{l}\text { Musella } \\
\text { et al. } 2011 \\
{[17]}\end{array}$} & $A(50)$ & $\begin{array}{l}\text { 3-0 polypropylene running } \\
\text { suture }\end{array}$ & 4 & 4 & 1 & \multirow[t]{2}{*}{$\begin{array}{l}\text { Bleeding, leaks: No } \\
\text { Strictures: Yes }\end{array}$} \\
\hline & $B(50)$ & No SLR & 2 & 0 & 2 & \\
\hline \multirow{2}{*}{$\begin{array}{l}\text { Albanopou- } \\
\text { los et al. } \\
2012[18]\end{array}$} & A (48) & GORE SEAMGUARDa & 1 & NA & 2 & \multirow[t]{2}{*}{ No } \\
\hline & $B(42)$ & 2-0 PDS running suture & 0 & NA & 0 & \\
\hline \multirow{3}{*}{$\begin{array}{l}\text { Dapri et al. } \\
2010[15]\end{array}$} & $A(25)$ & No SLR & NA & NA & 1 & \multirow[t]{3}{*}{ No } \\
\hline & $B(25)$ & GORE SEAMGUARD ${ }^{a}$ & NA & NA & 2 & \\
\hline & $C(25)$ & Running suture & NA & NA & 1 & \\
\hline \multirow[t]{2}{*}{$\begin{array}{l}\text { Present } \\
\text { study }\end{array}$} & $\begin{array}{l}\text { Clipping } \\
(50)\end{array}$ & No SLR (clipping) & 2 & 1 & 1 & \multirow[t]{2}{*}{ No } \\
\hline & $\begin{array}{l}\text { Oversew- } \\
\text { ing (50) }\end{array}$ & $\begin{array}{c}\text { 3-0 Biosync continuous } \\
\text { extraserosal invaginating } \\
\text { suture }\end{array}$ & 0 & 0 & 0 & \\
\hline
\end{tabular}

${ }^{a}$ Gore Medical/W.L. Gore \& Associates, Inc., Flagstaff, AZ, USA. ${ }^{b}$ Baxter Healthcare Corp., Deerfield, IL, USA. 'Covidien/Medtronic, Inc., Mansfield, MA, USA. $S L R$ - staple-line reinforcement. 
intraoperative decision to perform oversewing to control bleeding should be considered one of the outcomes. We also emphasize the need for a larger sample size.

Stapling devices make LSG a simple procedure, but complications related to the staple line are serious, costly, and sometimes fatal for patients [6, 10]. Despite advances in surgical stapling technology, rates of bleeding and leakage are about $1-5 \%$ [7], and more than $3 \%$ of LSG patients require reoperation [6]. These outcomes led to the concept of reinforcement of the staple line. Of the current methods of staple-line reinforcement, oversewing is one of the most popular among bariatric surgeons [11]. It is employed more often than buttressing using synthetic polymers or biologic tissue and is more effective at reducing the incidence of leakage and bleeding. However, there is no agreement as to the best suture material and suture technique to use.

The efficacy of oversewing the staple line is still unclear. Our review of the literature identified 4 papers [12-15], only 3 of which evaluated oversewing as a method of reinforcement [13-15]. We included 3 additional papers [16-18] not identified in our PubMed search. Running suture was one of the reinforcement techniques in all papers (Table V). The study by Carandina et al. [16], in which 600 patients were randomized to 4 groups, is the largest RCT of staple-line reinforcement conducted thus far. The interventions were no reinforcement, reinforcement with fibrin glue, and reinforcement with imbricating absorbable or barbed running suture. No significant differences in bleeding, stenosis, or gastric leak were observed among groups. The results of the present study support previously reported findings. However, there is sample bias in most studies of staple-line reinforcement. Because a sample size of $>1000 \mathrm{pa}-$ tients would be needed to reach statistical significance for postoperative bleeding and gastric leaks [12], the studies are unable to detect the differences between analyzed groups because of low power [13-18].

In addition, the majority of studies did not take suturing technique into account. Rogula et al. compared reinforcement techniques using suture on the staple line in sleeve gastrectomy. Their results suggested that continuous Lembert sutures may reduce the risk of staple-line leakage better than throughand-through sutures [19]. This suggests the importance of suturing technique.
The meta-analyses presented were not consistent with regard to the efficacy of oversewing; because the authors did not consider differences in suturing technique, the results are not reliable [7, 20-22]. There is a need for new studies on suture-line reinforcement.

We believe that other factors, e.g., stapling technique, can contribute to the risk of leakage. Each stapling device has advantages and disadvantages. A surgeon must be thoroughly familiar with the device and its use [23]. Also, the thickness of the gastric wall differs in each part of the stomach and is related to sex [24]. These factors suggest the need for research into choosing the appropriate stapler and optimal stapling technique. High sleeve pressure, stenosis of the sleeve, and local ischemia can also increase the risk of leakage. Because of the large number of potential confounders, we decided to focus on bleeding from the staple line, rather than leakage, as a primary outcome.

\section{Conclusions}

Our findings suggest that oversewing the staple line prolongs the LSG operation. Conclusions regarding the influence of oversewing on staple-line bleeding, postoperative leaks and stenosis, and length of hospital stay cannot be drawn. However, an important clinical finding was that $14 \%$ of patients allocated to the clipping group required additional oversewing of the staple line because of difficulties with hemostasis.

\section{Conflict of interest}

The authors declare no conflict of interest.

\section{References}

1. Angrisani L, Santonicola A, Iovino P, et al. Bariatric Surgery Worldwide 2013. Obes Surg 2015; 25: 1822-32.

2. Janik MR, Stanowski E, Paśnik K. Present status of bariatric surgery in Poland. Videosurgery Miniinv 2016; 11: 22-5.

3. Colquitt JL, Pickett K, Loveman E, Frampton GK. Surgery for weight loss in adults. Cochrane Database Syst Rev 2014; 8: CD003641.

4. Szewczyk T, Janczak P, Janiak A, et al. Laparoscopic sleeve gastrectomy - 7 years of own experience. Videosurgery Miniinv 2014; 9: 427-35.

5. Wassner JD, Yohai E, Hemlich H. Complications associated with the use of gastrointestinal stapling devices. Surgery 1977; 82: 395-9.

6. Frezza EE, Reddy S, Gee LL, Wachtel MS. Complications after sleeve gastrectomy for morbid obesity. Obes Surg 2009; 19: 684-7. 
7. Shikora SA, Mahoney CB. Clinical benefit of gastric staple line reinforcement (SLR) in gastrointestinal surgery: a meta-analysis. Obes Surg 2015; 25: 1133-41.

8. Chekan E, Whelan RL. Surgical stapling device-tissue interactions: what surgeons need to know to improve patient outcomes. Med Devices (Auckl) 2014; 7: 305-18.

9. Nedelcu M, Skalli M, Delhom E, et al. New CT scan classification of leak after sleeve gastrectomy. Obes Surg 2013; 23: 1341-3.

10. Bransen J, Gilissen LP, van Rutte PW, Nienhuijs SW. Costs of leaks and bleeding after sleeve gastrectomies. Obes Surg 2015; 25: 1767-71.

11. Rosenthal RJ; International Sleeve Gastrectomy Expert Panel, Diaz AA, Arvidsson D, Baker RS, et al. International Sleeve Gastrectomy Expert Panel Consensus Statement: best practice guidelines based on experience of $>12,000$ cases. Surg Obes Relat Dis 2012; 8: 8-19.

12. Shah SS, Todkar JS, Shah PS. Buttressing the staple line: a randomized comparison between staple-line reinforcement versus no reinforcement during sleeve gastrectomy. Obes Surg 2014; 24: 2014-20.

13. Aggarwal S, Sharma AP, Ramaswamy N. Outcome of laparoscopic sleeve gastrectomy with and without staple line oversewing in morbidly obese patients: a randomized study. J Laparoendosc Adv Surg Tech 2013; 23: 895-9.

14. Gentileschi P, Camperchioli I, D’Ugo S, et al. Staple-line reinforcement during laparoscopic sleeve gastrectomy using three techniques: a randomized trial. Surg Endosc 2012; 26: 2623-9.

15. Dapri G, Cadière GB, Himpens J. Reinforcing the staple line during laparoscopic sleeve gastrectomy: prospective randomized clinical study comparing three different techniques. Obes Surg 2010; 20: 462-7.

16. Carandina S, Tabbara M, Bossi M, et al. Staple line reinforcement during laparoscopic sleeve gastrectomy: absorbable monofilament, barbed suture, fibrin glue, or nothing? Results of a prospective randomized study. J Gastrointest Surg 2016; 20: 361-6.

17. Musella M, Milone M, Bellini M, et al. Laparoscopic sleeve gastrectomy. Do we need to oversew the staple line? Ann Ital Chir 2011; 82: 273-7.

18. Albanopoulos K, Alevizos L, Flessas J, et al. Reinforcing the staple line during laparoscopic sleeve gastrectomy: prospective randomized clinical study comparing two different techniques. Preliminary results. Obes Surg 2012; 22: 42-6.

19. Rogula T, Khorgami Z, Bazan M, et al. Comparison of reinforcement techniques using suture on staple-line in sleeve gastrectomy. Obes Surg 2015; 25: 2219-24.

20. Choi YY, Bae J, Hur KY, et al. Reinforcing the staple line during laparoscopic sleeve gastrectomy: does it have advantages? A meta-analysis. Obes Surg 2012; 22: 1206-13.

21. Gagner M, Buchwald JN. Comparison of laparoscopic sleeve gastrectomy leak rates in four staple-line reinforcement options: a systematic review. Surg Obes Relat Dis 2014; 10: 713-23.

22. Parikh M, Issa R, McCrillis A, et al. Surgical strategies that may decrease leak after laparoscopic sleeve gastrectomy: a systematic review and meta-analysis of 9991 cases. Ann Surg 2013; 257: 231-7.

23. Huang R, Gagner M. A thickness calibration device is needed to determine staple height and avoid leaks in laparoscopic sleeve gastrectomy. Obes Surg 2015; 25: 2360-7.
24. Rawlins L, Rawlins MP, Teel D 2nd. Human tissue thickness measurements from excised sleeve gastrectomy specimens. Surg Endosc 2014; 28: 811-4.

Received: 12.07.2016, accepted: 5.09.2016. 